\title{
Stability and variation in Office chants of the Sarum Sanctorale*
}

Much effort has been expended over the last century and a half in seeking to identify and explore the surviving evidence of the liturgical 'Use of Sarum'. This 'Use' constituted the medieval pattern of texts, chants, and ceremonial which saw its first flourishing at the early thirteenthcentury foundation of Salisbury Cathedral, and which, through widespread adoption, had become nearly universal across the ecclesiastical province of Canterbury by the time of the cessation of the Latin liturgy in the sixteenth century. Many transcriptions and facsimiles of the different Sarum liturgical books have been produced, and the medieval liturgy in England has figured substantially in liturgical and musicological studies of wider remit. Indeed, as Richard Pfaff has remarked, 'Sarum Use' is 'the single best known phrase pertaining to the medieval liturgy in England'. ${ }^{1}$ Until recently, however, very little has been done to differentiate between individual Sarum sources, owing to a widespread assumption that all liturgical manuscripts (and indeed printed books) of a particular type and Use are effectively identical. ${ }^{2}$ This assumption is, of course, convenient for any musicological scenario in which, for instance, a liturgical tenor (for instance, 'the Sarum melody for the fourth antiphon at Matins on the Second Sunday after Epiphany') must be identified. Such a chant could be readily supplied from Walter Howard Frere's Antiphonale Sarisburiense, a facsimile edition which is 'of a Manuscript of the thirteenth century' but actually includes plates drawn from three different sources. ${ }^{3}$

\footnotetext{
* I am indebted to the following individuals: my assistant Emily Lanigan, who helped with the task of transcribing chants; John Harper for advice and information about the Seymour fragments; Jennifer Rushworth for transportation and photography; and Julia Craig-McFeely and DIAMM for the loan of equipment. The Ranworth Antiphonal appears by the kind permission and the material assistance of the Rector and Wardens of St Helen's Church, Ranworth, Norfolk.
} 
This essay reports on the first comparative examination of any substantial quantity of chants from Sarum liturgical books for the Office, following on from work which has helped to show the heterogeneity of the textual contents of Office manuscripts in England. ${ }^{4}$ It considers in particular the chants for just four of the many feastdays which are present in the surviving manuscript sources as well as the first and only printed Sarum Antiphonal, or choir-book for the Office. $^{5}$ One hundred and sixty-four antiphons, responsories, and verses were studied individually and as a corpus, comprising the feasts of St Nicholas (which appears in Sarum calendars on 6 December), Saints Peter and Paul (29 June), the Assumption of the Blessed Virgin Mary (15 August), and St Cecilia (22 November). Each musical item and its text were transcribed, where present, from up to thirteen witnesses, all of which are identified as Sarum books, but whose contents betray a network of relationships and differences which point to a much greater degree of variance than might be assumed from this mutual identification.

The principal contention of this essay is that whilst there is usually a 'main' melodic reading or version for each chant, a considerable degree of variation exists among the readings from various witnesses. The data which support this argument allow manuscripts to be linked by networks of shared melodic material, both through melodic readings identical and present in multiple sources, and through divergences from such main versions. These observations help to illuminate something of the diversity of the written melodic tradition, raising wider questions about the relationship between written witness and performed reality, and about the fixity of 'Sarum Use', at least as far as it was transmitted in written form. 


\section{The expectation of uniformity}

Nothing in this essay is meant to denounce the work of previous or current students of 'Sarum Use', whose efforts have often been intended to supply a scholarly or practical need. In the case of the nineteenth- and early twentieth-century editorial work upon which so much subsequent scholarship has been based, this need was to rediscover and reconstitute the hidden past: the enthusiasm of the "learned group of "Sarum" scholars who formed [the] inner council" of the Plainsong and Medieval Music Society (publishers of Frere's Antiphonale) was dampened, wrote Dom Anselm Hughes, when it was learnt that the liturgy of Salisbury Cathedral owed much to Norman rather than English antecedents. ${ }^{6}$ Some more recent liturgiological projects have instead been designed to supply musical and ritual material for use within a wider musical context, as the strictures on public worship have been relaxed and the early music revival has necessitated the

exploration of the context for sacred polyphony. ${ }^{7}$ Both early and later investigations, particularly those involving editions for performance, have sometimes required pragmatic decisions which have limited the comprehensiveness of the enquiry. Nevertheless, it is clear that some earlier methodological presuppositions need to be reconsidered. Frere's Antiphonale was characterised as an authoritative, one-stop resource not by its editor but by its users. Another liturgiologist of the mid-twentieth century, Dom René-Jean Hesbert of Solesmes, chose to exclude outlying variants from consideration as he sought a 'restitution critique de l'archetype de la tradition'. Great effort was expended on research into the Mass, for reasons related to the centrality of that rite to the ongoing tradition of Christian worship. Pfaff has characterised the state of research into the Office as even more problematic: 'Anything like a critical edition, in the sense of one which establishes a base text and records variants from it, is with the breviaries that concern us almost a contradiction in terms.'9 
A rather reductive narrative of the adoption and spread of the liturgy of Salisbury Cathedral across southern England has also taken root; namely, on the basis of a remarkably large number of documentary and liturgical sources which prescribe or report the adoption of liturgy secundum usum Sarisburiensis in the statutes of ecclesiastical foundations, the assumption is made, sometimes explicitly, that the liturgical pattern of Salisbury was transported wholesale to a multitude of cathedrals, churches, and chapels. ${ }^{10}$ Conventional wisdom (or indeed inference) would suggest that this consistent and reliable liturgical usus was confected in the time of bishop Richard Poore, in the first quarter of the thirteenth century, and that, because of its superiority, it was copied widely and took root as the dominant liturgical Use of late medieval England, used everywhere from the eponymous cathedral to the smallest parish church. ${ }^{11}$ Quite how one cathedral's liturgy could have been executed in such a variety of venues has been explored in a practical context in the enactments of the AHRC-funded Experience of Worship Project, where the need to provide a 'performing edition' for use by clergy and musicians of some of the most frequent Sarum votive services illustrated many of the difficulties of the surviving sources: compiling the texts, chants, rubrics, and other instructions for Lady Mass, for instance, required multiple researchers to consult numerous volumes, and still sometimes to make assumptions and informed decisions, a potentially Procrustean task. ${ }^{12}$ Even individual books, designed for some specific venue and purpose, are often not in themselves sufficient repositories for their own local version of the liturgy. The promulgation of one cathedral's texts, chants, and rubrics across the south of England was executed in varying ways, from efforts to make generic any locationspecific rubrics or other texts clearly associated with the eponymous cathedral, to the opposite the re-introduction of local detail into generic rubrics. ${ }^{13}$ Every church, cathedral, and chapel 
which observed the 'Use of Sarum', as so many appear to have done according to documentary evidence, was dependent on local resources and local practice (including books, performers, and memory) to enact what was a local realisation of a rite with diverse textual and melodic readings. Within this nexus of influences there was limited scope for standardisation. Future research may wish to consider the potentially great number of discordant readings among the books used in a single venue.

In fact, before printing technology made the production of a large number of more or less identical copies of a volume possible, there was no definitive, entirely uniform breviary or antiphonal for any secular English Use; no source which, if consulted, would provide a satisfactory witness comparable to all others claiming the same origin. Indeed, the texts and chants which appear in the early printed breviaries and antiphonal do not always represent the prevailing tradition in the surviving manuscripts.

In the case of the musical aspects of the liturgy, which are inseparable from the texts to which they are set, much attention has been given to the comparison of single witnesses of disparate regional traditions in order to identify how they may be related, or to seek out the 'Ur-version' of a particular melody. Such studies, in their sampling of various regional differences, have done much to illustrate the diversity that may exist transregionally in the interpretation of a particular chant. However, they have also contributed, probably unwittingly, to the belief that all written versions of the same chant from one 'Use' or region are sufficiently identical not to warrant copy-specific comparisons. ${ }^{14}$ Hence, the most readily available source of Sarum chants is often 
deemed to be definitive; for the Office, this is typically Frere's composite facsimile, the ne plus ultra for scholars and performers of chant and polyphony of the present day. ${ }^{15}$

\section{The present investigation}

Taking now as read the argument that each manuscript needs to be treated as an individual, discrete witness and as a product of specific circumstances and influences (such as the local context) on its production (which, I wager, would be a basic assumption were the contents not liturgical ${ }^{16}$ ), it is now necessary to consider what further insights can be gained from multiple readings of the same melodies. The choice and order of the texts which were sung (principally antiphons and their psalms, responsories and their verses) are quite invariable amongst the surviving sources, and it seems likely that the dissemination of these texts and their order was helped not only by the spread of complete liturgical manuscripts but also by the promulgation in manuscript and print of the Sarum Ordinal, a volume whose express purpose was to indicate which texts were to be said and by whom. The relationship between the contents of the Ordinal and those of Office manuscripts is complex; some features, especially rubrics, are passed to and fro in the textual tradition. There may equally be reasons for melodic disparity: some differences may result from the ways that notation was read and transmitted (perhaps prioritising melodic contour over precise pitch, for example, or resulting from the intersection of the mnemonic function of notation and local memory), while others may have been caused by the 'drift' typical of manuscript transmission or by sheer random error.

Another key reason that the variability and transmission of Sarum chant have not been frequently studied is that there are very few musical manuscripts which survive from the cathedral or 
diocese of Salisbury with which to carry out comparisons; indeed, most of the surviving sources are also relatively late in date. However, recent research by Graham Bathe and John Harper has identified a number of fragments of Sarum liturgical manuscripts in the Wiltshire and Swindon Archives, including significant portions of the Temporale and Sanctorale of an Antiphonal. These fragments (termed here the 'Seymour fragments' after the collection in which they were discovered), appear to have been used in the Salisbury prebend of Bedwyn for at least 72 years on the basis of evidence from the Kalendar, and may have been given by one of the Cathedral canons who held the prebend..$^{17}$ Obits have been added to the Kalendar upon the death of prominent individuals from the area; these entries date from 1311 until 1383, and Bathe and Harper suggest that this gives the manuscript's 'local provenance [...] during the 14th century. ${ }^{, 18}$ The antiphonal's principal sections (Kalendar, Temporale, Sanctorale, and Common of Saints) are all represented over thirteen bifolia. ${ }^{19}$ The Sanctorale fragments give chants from the feasts of Nicholas, Peter and Paul, the Commemoration of Paul, Mary Magdalen, Laurence, the Assumption of Mary, the Inventio of the Holy Cross, and Cecilia. The rubrically conservative nature of the fragments means that they do not necessarily bear witness to anything which may betray a provenance close to the cathedral. Nor is there any trace of rubrical specificity relating to Bedwyn, a 'prebendal church of considerable resource' where 'elaborate liturgy was made possible on feast days by the attendance of clergy from nearby churches. ${ }^{20}$ Nevertheless, it is speculated that the complete volume may have been written before 1311, from an exemplar possibly before $1246 .^{21}$ The manuscript may also be a product of the Cathedral scriptorium, copied from an earlier exemplar held in the Cathedral itself. ${ }^{22}$ If this were the case, it would be the earliest and closest witness to the Office liturgy of Salisbury Cathedral, from a time when it was becoming more widely promulgated. 
The other natural terminus for a study of these chants is the printed Sarum Antiphonal (STC 15790/15790a) which stands near the end of the history of the Latin liturgy in Britain. A prodigious work, enormous in size, the Antiphonal was a product of the specialist Paris liturgical workshop of the printer Wolfgang Hopyl. It was produced in two halves: the first, in 1519, ran in its Temporale from Advent to Pentecost, and from 30 November to 20 June in the Sanctorale; the second, printed in 1520, ran from Trinity to Advent, and from 19 May to 29 November. As Magnus Williamson has convincingly shown, it is rich in editorial history, but until now has cast only a 'modest historiographical shadow' despite being an 'unmistakably Renaissance' effort: a Latin volume edited in Cambridge, sold in London by a German, and made in Paris by a Dutch printer. $^{23}$

The 1519-20 Antiphonal was the only complete book of chants for the Sarum Office to be printed (there were various editions of the Hymnal). By way of comparison, there were numerous breviaries and missals, and even four editions of the Gradual. How it was constructed, therefore, is a matter of some interest. Which exemplars might have been used? How were the contents redacted? Some evidence for these processes is contained within the Antiphonal itself: Williamson reports that the Psalter (which appeared in each of the 1519 and 1520 volumes) was produced in two different impressions. ${ }^{24}$ More importantly, there is a letter of commendation from Brian Rowe, vice-provost of King's College, Cambridge, which indicates that the Antiphonal was edited by 'egregius doctor Sampson', who was, according to Williamson, among a number of King's and Eton men involved in 'liturgical consultancy': Cowper of Magdalen College, Oxford, later fellow of Eton, edited the Sarum Diurnale published by Hopyl and 
Birckman (the same publishing partnership), and William Clerk, precentor of King's, had revised the Directorium Sacerdotum (a rationalisation of the Sarum Ordinal) of Clement Maydeston. ${ }^{25} \mathrm{~A}$ further benefit of the printed Antiphonal was that purchasers were able to 'assume its compatibility with associated books from the same publisher'; certainly in relation to Sarum books edited by Sampson. ${ }^{26}$ This seems to bespeak an anxiety about different melodic traditions in different books and an implicit concern about the convergence of different readings. Insights into whether, and how, the distinguished doctor Sampson redacted a heterogeneous manuscript tradition to produce the contents of the 1519-20 Antiphonal may be discernible if this witness is compared with the surviving manuscripts. As will be seen, there is a meaningful connexion between Sampson's edition and the principal source for Frere's facsimile Antiphonale.

In addition to these termini, there are a number of other manuscripts of the Office chants still extant: those which are considered in the present study are detailed below, representing a significant proportion of the surviving witnesses, together with the Seymour fragments and the printed Antiphonal: 
Aberystwyth, National Library of Wales

- $\quad$ MS 20541.E, the 'Penpont Antiphonal' (14th century; associated with Brecon/Talgarth)

Cambridge, University Library

- MS Mm.II.9, Frere's main source for the Antiphonale Sarisburiense (13th century; allegedly Barnwell, Cambs)

- $\quad$ MS Additional 2602 (14th century, used in Springfield, Essex)

Chippenham, Wiltshire and Swindon Archives

- The 'Seymour' Sanctorale fragments, WSA 9-14-338d-g, 9-24-460, 9-15-57 (13th century; Salisbury Cathedral? then Bedwyn, Wilts)

London, British Library

- $\quad$ Additional MS 28598 (14th century; South of England)

- $\quad$ Lansdowne MS 461 (15th century; Diocese of Norwich)

- $\quad$ Lansdowne MS 463 (15th century; Diocese of Norwich)

Nottingham, University Library

- MS 250, the 'Wollaton Antiphonal' (15th century; East Anglia then St Leonard's Church, Wollaton, Notts)

Oxford, Bodleian Library

- $\quad$ MS Bodley 948 (15th century; London)

- $\quad$ MS Lat liturg. b.14 (14th century; Denchworth, Bucks)

- $\quad$ MS Laud misc.299 (15th century; East Anglia, then Launton, Oxon)

Ranworth (Norfolk), St Helen's Church

- $\quad$ s.n., 'the Ranworth Antiphonal' (15th century; Ranworth, Norfolk) 
The discovery of the Seymour fragments, and the need to place them in context, reminds us that it is necessary to evaluate the stability or heterogeneity of chants from the Sarum Sanctorale in their manuscript witnesses to an extent that has not yet been carried out, or indeed carried out at all. Equally, in such an investigation it would be remiss not to consider the melodic tradition of the 1519-20 printed Antiphonal, said to be a product of authoritative redaction and precise workmanship. This study seeks to establish, based on the surviving witnesses, the degree to which Sarum chant books for the Office contained a uniform melodic tradition.

\section{Methodology}

The corpus of melodic data used in the present study comprises transcriptions of the entirety of the text and music (excluding unchanging psalm-tones) of the offices for St Nicholas, Saints Peter and Paul, the Assumption of the Blessed Virgin Mary, and St Cecilia from each of the twelve manuscript sources and the 1519/20 Antiphonal. ${ }^{27}$ The choice of these feasts stems from the fact that, with the exception of a few witnesses of Cecilia's office, they appear complete in each of the sources. These transcriptions were entered into a FileMaker database which allowed each source's reading of a chant to be compared visually and electronically. A number of automated scripts allowed some initial sorting to be done; for instance, the computer checked, for each item (which I shall use as a generic term for any antiphon, responsory, or verse), whether transcriptions from any two or more manuscripts were entirely identical, pitch-for-pitch. The database noted all instances of this shared melodic version and isolated for further study all other readings of the melody. This analysis explicitly did not seek to identify or privilege any 'base' or 'original' version of a melody, but it did record instances where there were two or more 
witnesses which had exactly the same melody. The most frequently occurring of these instances, where more than one exists, is here termed the 'main melodic version'. Many of the following analyses consider the presence or absence of the main melodic version; however, when no two readings were identical throughout it was possible to identify melodic gestures where two or more witnesses diverged from the majority. Lists of such shorter shared melodic divergences (or 'variants') were collected such that for every witness it is possible to show how many of these divergences it shares with every other witness.

\section{Analysis}

As mentioned, one hundred and sixty-four items were transcribed, principally antiphons (including the Invitatory antiphons) and responsories and their verses. Three-quarters (123 out of 164 , or $75 \%$ ) have a consistent melody that appears identically in two or more sources, namely the 'main melodic version'. To add some context to this figure, the main version appears in the majority of sources (at least 7 out of 13) in just over half (88 out of 164, or 54\%) of the chants. The average number of witnesses sharing an item's main melodic version is 4.5 (out of 13). These figures suggest that for a considerable majority of items within these offices there was a melody which was transmitted, precisely enough to be identical, in a significant number of unrelated witnesses. In just under a quarter of items, especially responsories which were longer and contained substantial melismas, this was not the case. The following observations relate to the main melodic version for each item. 


\section{The main melodic version by service and genre}

Table 1 (at the end of this article) shows, for each of the principal services of each Office, the average number of witnesses which give the main melodic version. In the Office for the Assumption, the psalm-antiphons (and Benedictus antiphon) at Lauds are markedly uniform across all witnesses, compared with those for Vespers. Similar results are observed for other Offices; indeed, the consistency of items at Lauds is always higher than for the two other principal services. The low average for Vespers of Nicholas relates to the fact that two of the four chants used for this calculation are a relatively long responsory and its verse, in whose sources more variation is present than in the comparatively short, syllabic antiphons in other offices. Except in the Office for Cecilia, the lowest average appears in Vespers rather than in Matins, an unexpected observation since there are nine long responsories, but the effect of these longer chants seems to be averaged out by nine short, consistent psalm-antiphons.

When chants are separated by genre, it is clear that the chants of Matins responsories (which are typically longer than most of the other chants) tended to be identical across considerably lower number of witnesses: 2.8 witnesses on average compared with 4.5 identical witnesses across all genres. Antiphons (appearing identically in an average of 4.7 witnesses) are slightly more consistent than the whole corpus. The highest consistency is, however, within the psalmantiphons of Lauds (average 6.5 witnesses), a predictable result since they are typically short, syllabically set melodies. Similarly, the verses of Matins responsories, together with Matins antiphons, both concise genres, have relatively high average numbers of identical witnesses (5.5 and 5.1 respectively). Vespers antiphons (including the Magnificat antiphons) however, owing to a number of long melodies especially in the Office for the Assumption, had an average of 3.6 
witnesses giving an identical reading. Magnificat antiphons alone had a somewhat higher average, of 4.4. These observations confirm the expectation that the genres with shorter and more syllabic melodies are more likely to have a main melodic version shared by a large number of witnesses, while responsories, members of the most complex melodic genre, are much less likely to be identical among witnesses. ${ }^{28}$

While a great number of items (99) have only a single melodic reading which at least two manuscripts share, others have up to three different such readings. Of the ten items with three different shared readings, five were chants from the Assumption, three from Peter and Paul, and two from Nicholas. Five were antiphons, three verses, one a responsory, one a Matins invitatory; seven from Matins, one from Vespers, and one from Lauds. In this group, the average number of witnesses sharing the main melodic version was 3.7 (ranging from 7 to 2). Two example chants, with the main melodic version and a number of variants, may be found later in this essay.

\section{The main melodic version by feast and by witness}

Some manuscripts transmit the main, or most frequently occurring, melodic version with a good deal of consistency; others do not. This observation, and the fact that individual witnesses of each office demonstrate a range of different influences, may be seen when the copies of each office are compared. The averages across four offices (56\% main melodic version for the Assumption; 53\% Nicholas; 52\% Peter and Paul; 47\% Cecilia) are reasonably similar, but consideration of the detailed results by individual witness yields further insights. This section shows the breakdown by feast. In fact, these averages mask some extremes, which will be discussed later. Table 2 (at the end of this article) gives full details. 
Individual witnesses of the Office for the Assumption contained up to $77 \%$ of the main melodic version, and as little as $20 \%$, although most fell somewhere between these termini: the percentages for all witnesses of the Assumption had the lowest standard deviation ${ }^{29}$ of the four feasts, meaning that a relatively consistent proportion of the office followed the main melodic version. Four manuscripts (Lansdowne 461, Lansdowne 463, Bodley 948, Cambridge Mm.II.9) and the printed Antiphonal gave between $66 \%$ and $77 \%$ of the main reading; four other manuscripts had percentages between 54\% and 57\%; those containing the least were BL Additional 28598 (40\%), NLW 20541.E (34\%) and Cambridge Additional 2602 (20\%).

Witnesses of the office for St Cecilia give both the highest and lowest percentage of the main melodic version (Lansdowne 461 at 93\%, and Cambridge Additional 2602 at 4\%), and consequently the highest standard deviation, across all four offices. ${ }^{30}$ Three other witnesses give over $70 \%$ of the main melodic version: Bodley $948(81 \%)$, Wollaton (78\%), and the printed Antiphonal (74\%). At the opposite extreme, Bodl. Laud misc. 299 and NLW 20541.E give 7\%. For these reasons, it seems that the main melodic version may be very well distributed among some of the sources, whilst others which depart from it are consistently, and considerably, more divergent.

Witnesses of the office for St Nicholas contain from $79 \%$ to $21 \%$ of the main melodic version, whilst the standard deviation is similar to that for the Assumption. Seven sources have over 50\% of the main melodic version for this office. The printed Antiphonal is the seventh of these, and it should also be noted that in its contents the office for Nicholas has the lowest proportion of the 
main version. Nicholas's office also hints that the contents of Bodl. Laud misc.299 are inconsistent in their adoption of the main melodic version, standing apart from the other manuscripts since nearly eighty percent of its Nicholas office gives the main melodic version, yet for only $7 \%$ of its Cecilia office is this true. By way of contrast, the same manuscript gives $44 \%$ of the main version for the Assumption, and 54\% for Peter and Paul. This observation should highlight the fact that various influences are at work within a single manuscript and it therefore should not be thought that the reception and consistency of chants was uniform throughout the Sanctorale.

The office for Peter and Paul appears with between $79 \%$ and $15 \%$ of the main melodic version: Lansdowne 461 contains the greatest proportion and BL Additional 28598 the smallest. Most witnesses fall evenly between these extremes, though seven give the main melodic version in more than half of the office.

It is clear that there are different influences on the transmission of the chants of the Sanctorale which did not necessarily work in the same ways across the various offices, meaning that in a single manuscript one office may largely follow the main melodic version, and another may not. It is therefore worth identifying the six witnesses which always give the main melodic version in at least $50 \%$ of the chants of each office: these are Lansdowne 461, Bodley 948, Cambridge Mm.II.9, Ranworth, and Wollaton, together with the printed Antiphonal. Similarly three witnesses always give less than fifty percent of the main reading of the chants of each office: these are BL Additional 28598, Camb. Additional 2602, and NLW 20541.E. In sum, it would appear that while there may be specific influences on the appearance of chants in each witness, 
the transmission of particular offices may have been subject to further stimuli. Further research may wish to investigate melodic evidence for hints about the transmission and stability of individual chants.

Brief observations by witness, based on Table 2 (at the end of this essay), are given below, reflecting on the percentage of the main melodic version given in each.

Printed Antiphonal: main melodic version ranges from 58\% to $74 \%$ (SD 6). Relatively consistent except for Nicholas.

BL Additional 28598: main melodic version 15\%-40\% (SD 11). A real outlier.

BL Lansdowne 461: main melodic version 63\%-93\% (SD 11). A strong witness of the main melodic version.

BL Lansdowne 463: main melodic version 38\%-74\% (SD 16). A striking disparity: 38\% of the main version for Nicholas, $74 \%$ for the Assumption (a difference of 36\%).

Bodl. Bodley 948: main melodic version 67\%-81\% (SD 6). Consistently high appearance of the main version; lower for Nicholas.

Bodl. Lat. liturg. b.14: 30\%-54\% main melodic version (SD 9). Middling.

Bodl. Laud misc. 299: 7\%-79\% main melodic version (SD 26). Very striking disparity, which shows that results for one office may not predict those for another.

Camb. Additional 2602: 4\%-25\% main melodic version (SD 8). Another significant outlier (Cecilia lowest); but even within these four offices there is a $21 \%$ disparity.

Camb. Mm.II.9: 62\%-69\% main melodic version (SD 3). The main version appears a consistent percentage of the time across four offices.

NLW 20541.E: 7\%-34\% main melodic version (SD 11). At quite a distance from the main tradition.

Ranworth: 52\%-71\% main melodic version (SD 7). Cecilia and Assumption $<60 \%$, but Peter and Paul $71 \%$. 
Wollaton: 54\%-78\% main melodic version (SD 9). Cecilia quite high; Assumption percentage lowest (again illustrating independence of the four offices).

Melodic readings (including but not limited to the main melodic version) were tabulated (see Table 3, below) in order to show, for each witness, the number of items where it shared a melody with others. The manuscripts which proved most likely to have melodic material in common with at least one other witness were British Library Lansdowne 461 (sharing an identical reading with at least one other witness in 99 items), Bodl. Bodley 948 (97 items), and the Wollaton Antiphonal (91 items). These manuscripts were also the most likely to have the main melodic version, as Table 3 below indicates.

There is a strong and predictable correlation between manuscripts which share a large amount of material with others, and those which frequently follow the main melodic version. It is also possible to consider the closeness of each witness to the main melodic version: strikingly, nearly eighty percent of Lansdowne 461's chants for these four offices are the same as the main melodic version, thirteen percent higher than that of the printed Antiphonal (67\%) and Cambridge Mm.II.9, the main source for Frere's Antiphonale and the typical resource of first resort for 'Sarum' office chants. Three manuscripts, therefore, are in fact more representative of the wider tradition than the ostensibly edited printed version. At the bottom of the table are Cambridge Additional 2602, British Library Additional 28598, and NLW 20541.E, all fourteenth-century sources which share as little as $13 \%$ of the contents studied with at least one other witness. Additional 2602 and NLW 20541.E are otherwise related by shared variants from the main melodic version, as will be shown below. The Seymour fragments are also notable even though only forty-eight items are transcribed, because fully thirty-one of these items (65\%) give 
the main melodic version. This result places the fragments considerably closer to the main tradition than the other early sources, and reasonably close to the results for the printed Antiphonal.

It is obviously worth considering whether the printed Antiphonal, one of the last witnesses temporally, a product of redaction in Cambridge, and the only printed witness, is representative of the melodies which predominate in the manuscript tradition. It seems as if the marketing rhetoric emphasising the accuracy of the printed Antiphonal, despite the frequent use of such verbiage as a mere marketing ploy, may be credible: sixty-seven percent of the contents of these offices are identical with the dominant version in the manuscripts (the main melodic reading), meaning that in around two-thirds of the items studied the printed Antiphonal is an accurate reflection of the manuscript tradition, but necessarily that the other third is less representative; consequently several manuscripts do a better job of containing more of the dominant melodic reading.

Equally it is worth considering the case of Cambridge Mm.II.9, used by Frere as the principal source for the facsimile Antiphonale. Ninety-eight items were transcribed (the office for Cecilia is missing in the manuscript, which ends imperfectly). Here in 66 out of 98 cases (67\%) the manuscript coheres with the main melodic version - the same percentage as for the printed Antiphonal, and quite similar to the result for the Seymour fragments, which, as we have noted, were used and possibly made close to Salisbury Cathedral at the start of the wider dissemination of its liturgies. 


\section{Affinities between witnesses}

The following tables show, for each witness, how many of its chants are identical to the reading in every other witness. Each chant has a distinctive melody with identifiable features, but for each such melody there are also a multiplicity of different 'readings' which, when shared by two or more witnesses, can betray precise melodic affinities. Table 4 (at the end of this article) shows the affinity of each witness to every other witness, by indicating the number of items for which the pair shares an identical reading and also by number of shared variants from the main melodic version.

Looking at each manuscript paired with every other in Table 4, the strength of these pairings may be seen in their range: Lansdowne 461 shares nearly fifty percent of the four offices pitchfor-pitch with Bodley 948 and only 7\% with BL Additional 28598; similarly, Additional 28598 shares only $14 \%$ of its contents with its closest relative, Cambridge Mm.II.9. It is also at a distance from the divergent tradition of NLW 20541.E and Cambridge Additional 2602, although it shares a number of melodic variants with the latter.

Lansdowne 461 and Bodley 948 share the greatest number of identical readings, whereas NLW 20541.E and Cambridge Additional 2602 share the fewest (if the incomplete Seymour fragments are excluded).

Other than Bodley 948, Lansdowne 461 is the closest relative of four other manuscripts (Laud misc.299, Mm.II.9, Wollaton, and NLW 20541.E), and Bodley 948 is the closest to four others (including Lansdowne 461 and the Seymour fragments). The printed Antiphonal is closest to 
Bodl. Lat. liturg. b.14, but only by a small margin ahead of Lansdowne 461. Further affinities are identified in the following table.

It is also notable that the thirteenth-century manuscript Cambridge Mm.II.9, the main source for Frere's Antiphonale, is closest to Lansdowne 461 and the printed Antiphonal. These seem to be among the sources at the centre of the melodic tradition. Thus Mm.II.9, if it is archetypal of early sources as Frere claims, may suggest at least some degree of fixity in the melodic tradition from the late thirteenth century until the early sixteenth. It is also worth mentioning that Mm.II.9 has been frequently identified as an Augustinian manuscript from Barnwell, Cambridgeshire. Pfaff does not think so, and his contention may be upheld by the consistency of this manuscript's melodies with those of the majority of the definitively Sarum sources. Frere, of course, also thought it a representative manuscript, and his belief, too, seems to have been upheld. The closeness of Mm.II.9 to the centre of the Sarum tradition contradicts the idea that as a reportedly Augustinian manuscript it should not cohere with normative Sarum contents. This observation may support Pfaff's assertion that Mm.II.9 was not used at an Augustinian house (or if it was so used, it contradicts some work done which suggests that Augustinians had their own melodic traditions, in contrast to the long-held belief that they typically adopted the local pattern. ${ }^{31}$

\section{Shared variants from the main melodic version}

A contrasting means by which it was possible to show associations between witnesses was by the number of variants from the main melodic version. Sums are given in Table 4 for each pairing of manuscripts, for information, in the 'Shared variants' column. Only a summary of the most important observations is given here. 
Fully sixty percent of such variants involved either a greater or fewer number of pitches in the variant reading; about 18 percent involve one or more pitches 'transposed' by some interval; fewer than half of these involve more than one pitch. Only ten percent of variants involved the addition or omission of repercussions or repeated notes from the main reading. As a general rule, very few shared variants involved more than a few pitches at a time. Some, therefore, may be a result of the same random processes which may have corrupted the main melody, but it is not realistically possible to be any more productively speculative about the reasons for these melodic divergences.

\section{Characteristics of shared melodic variants:}

$31 \%$ Variant contains fewer pitches than main reading

29\% Variant contains more pitches than main reading

13\% Transposition of a single pitch by any interval

6\% Transposition of multiple pitches by any interval

6\% Entirely different melody

$5 \%$ Change in underlay

$10 \%$ Other variant

Pairings of manuscripts by shared variant, as noted in the tables, can give a different picture of affinity. Cambridge Additional 2602 and NLW 20541.E, for instance, share six identical melodies and also share thirty-two melodic variants from the main reading. Similarly, Cambridge Additional 2602 and BL Additional 28598 only share nine items with identical melodies, but 
twenty-three melodic variants. The average number of shared variants between pairs of manuscripts (in the tables above) is 6.4. As a general (and predictable) rule, the greater the number of shared items with identical melodies, the smaller the number of shared variants.

Two chants with shared variants are printed below, to illustrate some of the different types of divergence from the main melodic version. In the first example, Matins antiphon 4 from Cecilia's office, the main melodic version appears pitch-for-pitch in five witnesses. A very similar reading may be found in the others, with the variant on 'suam' shared by all but one of the divergent witnesses, while Camb. Additional 2602 has more substantial changes to contour alongside a transposed and slightly modified setting of 'ieiuniis'.

Cecilia, Matins antiphon 4 Biduanis ac triduanis (mode 2)

Main melodic version

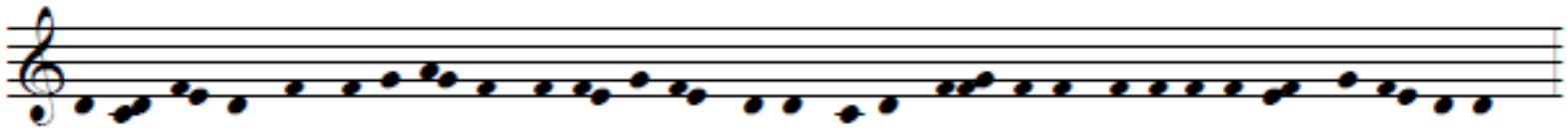

bi-du- a- nis ac tri-du-a- nis ie-iu- ni- is o-rans suam do- mi-no pu-di-ci-ti- am com-men-de-bat.

Bodl. Lat liturg. b.14, Bodl. Laud misc. 299, Seymour

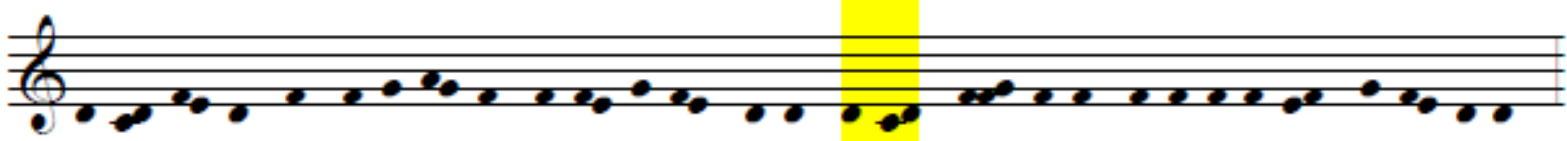

bi-du- a- nis ac tri-du-a- nis ie-iu- ni- is o-rans suam do- mi-no pu-di-ci-ti- am com-men-de-bat.

NLW 20541.E

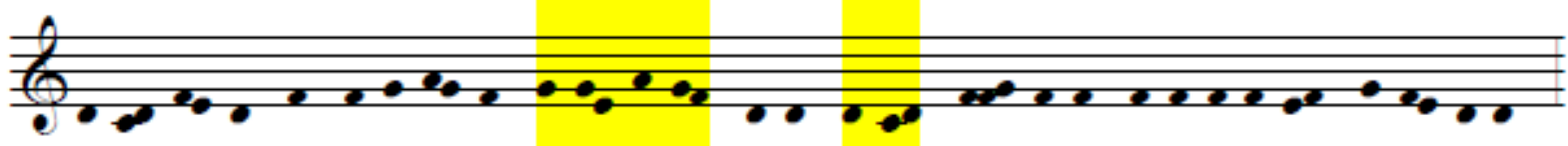

bi-du- a- nis ac tri-du-a-nis ie-iu- ni- is o-rans -suam do- mi-no pu-di-ci-ti- am com-men-de-bat.

Camb. Additional 2602

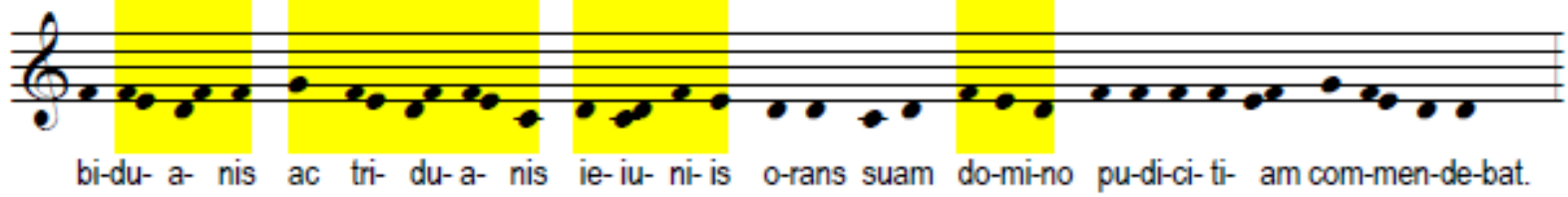


The second example treats the final word of the fifth Matins responsory for Nicholas. All melodic variants within this word appear on the melisma on the syllable '-men-' which, in the main melodic version, contains two successive instances of the melodic string $c d c f f g f e c d b c c$. Both instances are preserved in the readings in the printed Antiphonal and Ranworth, both of which do have minor variants (extra pitches in both cases). The first instance of this melodic string is preserved complete in NLW 20541.E, BL Lansdowne 461, and BL Additional 28598, whose additional variants may be seen below: they share the use of $b c c$ instead of $b c c c$. The second instance of the string is preserved in Wollaton and Bodl. Lat. liturg. b.14, in both of which a minor variant may be found at the top of the contour of the first instance.

Nicholas, Matins responsory 5 Qui cum audissent (mode 5)

Main melodic version

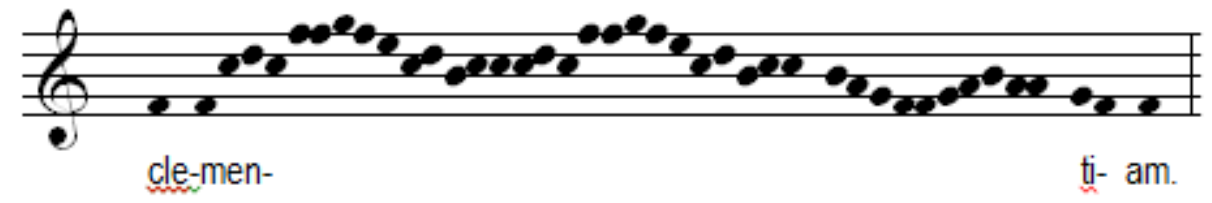

1519-20 Antiphonal

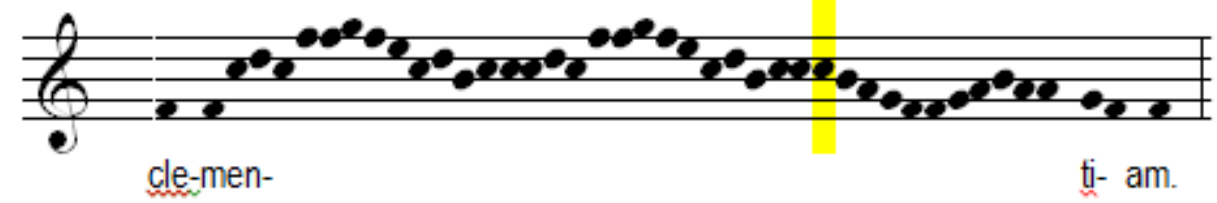

Ranworth

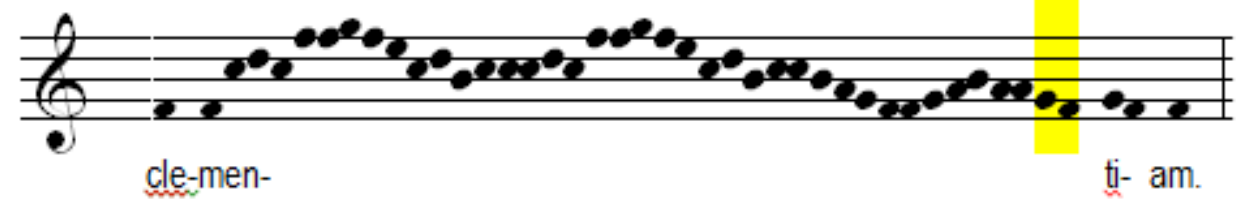

NLW 20541.E

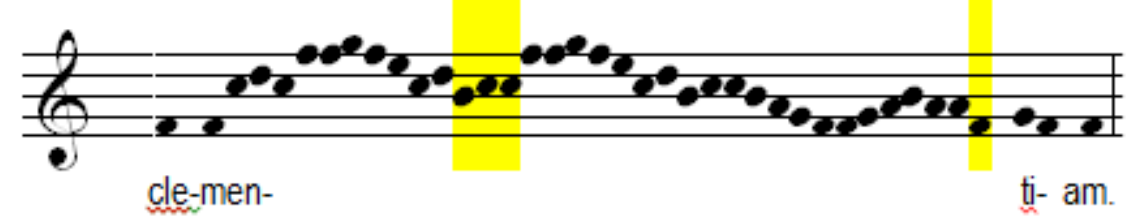


BL Lansdowne 461

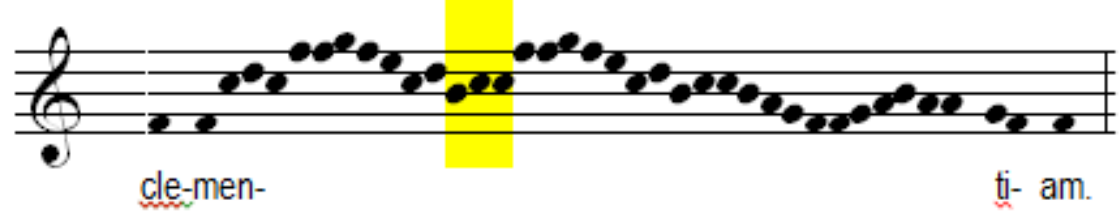

BL Additional 28598

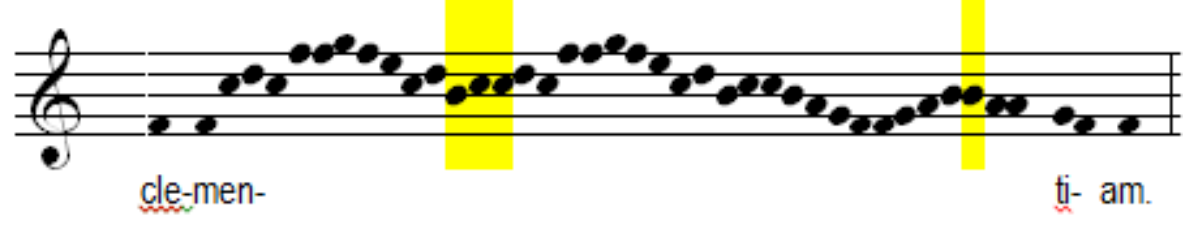

Camb. Additional 2602

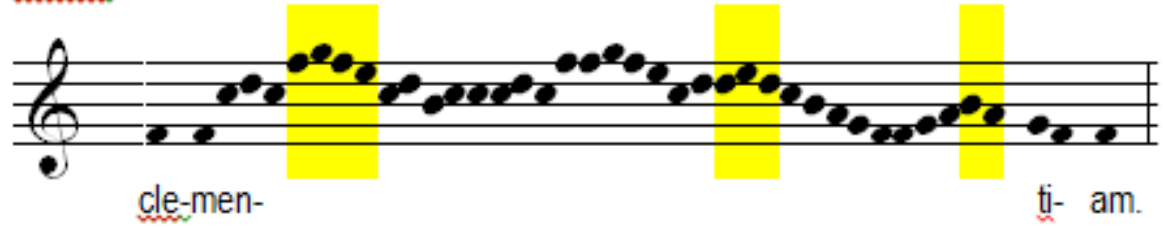

Wollaton

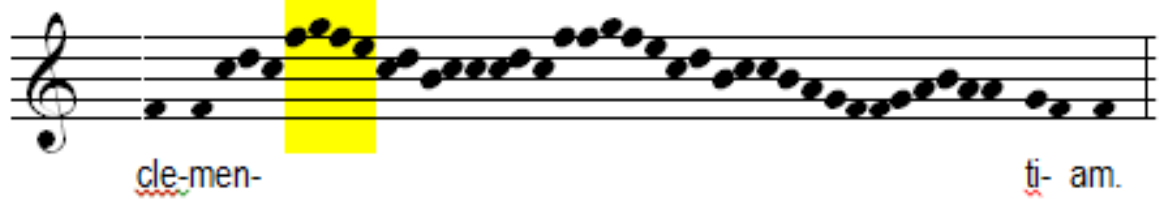

Bodl. Lat. liturg. b.14

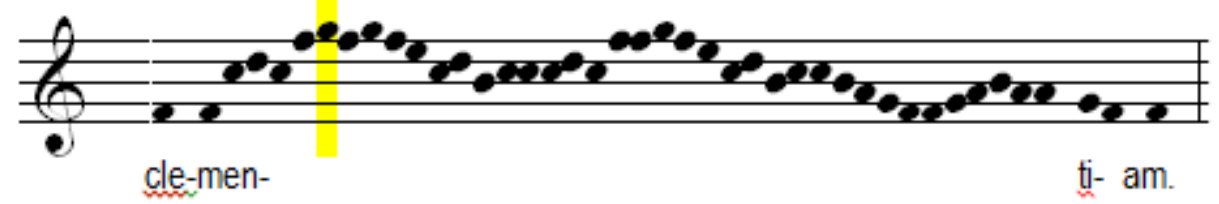

\section{Discussion}

These large-scale analyses show that while the choice and order of chants for the four feastdays are consistent, the precise melodic readings in each witness help to illustrate affinities between them. It is clear that some witnesses are much closer to a majoritarian melodic tradition than others, with chants in BL Lansdowne 461 five times more likely than those in Cambridge 
Additional 2602 to appear in the most frequent melodic version. About two-thirds of the contents studied from the printed Antiphonal, and an equal proportion from Cambridge Mm.II.9, give the main melodic version. ${ }^{32}$ This is a smaller proportion than that found in several of the manuscripts, but the printed Antiphonal is still considerably more faithful to the main melodic version than NLW 20541.E, BL Additional 28598, and Cambridge Additional 2602, less than a quarter of whose contents give the main reading. Given the very considerable disparity between these three manuscripts and the main version, and the frequency of shared variants between them, it may be that they form a sub-grouping of melodic versions outside a 'main' family including the other witnesses. Clearly, the exemplar(s) for the printed Antiphonal were well chosen, although we are no closer to identifying any sources used by its editors save the likelihood that they were manuscripts similar to the tradition in Lansdowne 461, Bodley 948, and Cambridge Mm.II.9. The other early witness, the Seymour fragments, gives a percentage of items corresponding to the main melodic version which, at $65 \%$, is close to the two-thirds in the printed Antiphonal and in Mm.II.9.

\section{Manuscript survival}

These results provide an empirical and unambiguous assessment of a significant sample of the Sarum liturgical material that survives, but are these results representative of the wider melodic and textual tradition of the thousands of manuscripts which were produced and used at the height of liturgical provision in the late Middle Ages? Owain Tudor Edwards has postulated that something like 24,000 antiphonals might have existed across England and Wales around the middle of the sixteenth century, with perhaps as many as 20,000 of those being Sarum: therefore, 
the rate of survival is something like $0.1 \% .{ }^{33}$ Records of visitations and inventories supply much data for Edwards's enquiry: for instance, the Registrum de ornamentis ecclesiarum archidiaconatus Norwyci of 1368 shows that in the archdeaconry of Norwich ninety-five percent of the 358 parish churches had at least one antiphonal. Reportedly, two or three was average, and a few churches had five or six. Edwards shows that there were about a thousand antiphonals in the parish churches of Norfolk alone at the end of the fourteenth century. ${ }^{34}$ Even in the thirteenth century bishops were keen to ensure the churches in their care had an appropriate number of volumes. Richard Pfaff reports that in 1240 Walter de Cantilupe, bishop of Worcester, ordered that parish churches ought to have the following: breviary, antiphonal, gradual, troper, manual, psalter, ordinal; similarly, Bishop Peter Quivil of Exeter prescribed a 'missale bonum [?]', gradual, troper, 'manuale bonum [?]', legenda, antiphonarium, psalterium, ordinale, venitarium, hymnarium, collectar. ${ }^{35}$ Williamson suggests that antiphonals were only replaced when 'completely worn out, or in the case of some regional uses, liturgically obsolete $[; \ldots$ therefore $]$ an early Tudor worshipper $[\ldots]$ would probably have seen a heterogeneous collection of new and old Antiphoners, unitary volumes, and Sämmelbande [or composites] ${ }^{36}$ The statutes for the foundation of Ottery St Mary (near Exeter) suggest that three singers should ideally sing from one volume; and Ottery was to be provided with three antiphonals, three psalters, and three graduals on each side of the choir-step. ${ }^{37}$ In 1384 , St George's Chapel, Windsor was reported to have eleven breviaries (nine noted); five antiphonals (three with psalter, and one separate psalter), and eight graduals, among other volumes. ${ }^{38}$ Having reported these facts, Frank Harrison noted that 'In the earlier Middle Ages much of the ritual music was sung from memory' and even at Ottery at Matins of simple feasts the boys were to sing the beginning of the responsory and its verse 'without book or light'. ${ }^{39}$ Such a statement, added to the previous anxieties about 
frequent minor inconsistencies between volumes, helps to raise the question, were books in quire actually being read word-for-word, pitch-for-pitch? The memorisation of the Psalter, common tones of the Office, Lady Mass and Office, the Office of the Dead, and other frequentlyperformed material seems relatively straightforward. But how far might this capacity for memorisation go in terms of complicated, melismatic chants which were only sung once a year? The results of this study seem to show a central tradition within which the printed Antiphonal is found. What of the manuscripts with very few chants following the main melodic version? Do they denote a divergent tradition learnt other than from the dominant written sources? How might such an aural tradition have existed alongside contradictory manuscript readings?

The convention that clerks were expected to know large quantities of chant by heart seems to have persisted at least to the latter part of the fourteenth century. Bowers reports that in 1318 at Wells it was agreed that in order to encourage the canons themselves (not, seemingly, the vicarschoral) to come to Matins, they might be excused the obligation of memorising the service, and might instead bring their books and lights with them. ${ }^{40}$ Yet, 'a vicar-choral needed to have [...] committed to memory the entire corpus of plainsong chant, being able to sing every service without recourse to any book', and vicars-choral at Wells were obliged to spend their first year on probation, 'having sworn that 'he would work diligently to learn the Psalter, Antiphoner and Hymnal by heart'. ${ }^{41}$ Bowers also reports the 1389 case of William Elys, a probationer vicarchoral of Salisbury, who was submitted to an examination of his knowledge of chant, with the seeming assumption that memorisation of the psalter, hymnal, and antiphonal was normative. The chapter "“did immediately examine him in the psalter - in the psalm Quam bonus; in the hymnal - Tu civitatis unitas; in the antiphoner - in the responsories at Matins on the octave of St 
John the Evangelist; and in other items in the psalter, hymnal, and antiphoner. Out of which, the examinee knew how to repeat, without book, neither the psalm, nor the hymn, nor the responsory, not one nor another.", 42

Reminders of seemingly inhuman medieval feats of memory may, however, distract us from some fairly unambiguous evidence of redaction, even of existing manuscripts. The fourteenthcentury statutes of St George's Chapel, Windsor required that, within three years, all the service books of the chapel should be checked for correctness. ${ }^{43}$ The chapter did more than this, however, and in 1362/3 one of the canons, John Aleyn, and one of the vicars-choral, Adam Pencrich, spent eighty-six days in Salisbury at the cathedral, having taken the chapel's books with them in order to correct them against manuscripts from the source. Bowers identifies Aleyn with the composer of the same name in the Old Hall manuscript. ${ }^{44}$ Barbara Haggh's study of the printed Cambrai antiphonal indicates a similar process of checking the accuracy of chants in that foundation. ${ }^{45}$

To return to the original point, it might be said that the present results are affected by the fact that so many manuscripts did not survive. But in those which do (of which these twelve are a sample) it is clear that melodies, while consistent in basic features, tolerated an amount of variation within a relatively stable corpus (given that there is a frequently appearing main melodic version for nearly all items studied here). But even the most closely related pair of manuscripts share only $48 \%$ of their melodies, far from the imagined total of one hundred percent in a world where all manuscripts are identical. Within individual manuscripts, too, different influences on different 
offices seem to have held sway: Bodl. Laud misc. 299 has $79 \%$ of the main melodic version for Nicholas's office, but only $4 \%$ of Cecilia's.

It is appropriate here to summarise some of the principal observations of this enquiry into the melodic tradition of four offices of the Sarum Sanctorale:

- For a considerable majority of chants there is a main melodic version; in just over half of these the main melodic version is represented in at least $50 \%$ of the witnesses;

- Chants belonging to genres which are typically shorter and more syllabic are more likely to have a main melodic version shared by a large number of witnesses; this observation may help to explain why the antiphons of Lauds are more likely to correspond to the main melodic version;

- The consistency of one office in a manuscript may not be a good predictor of other contents, and some offices may be more uniform across a variety of witnesses;

- Manuscripts vary considerably as to the extent they contain the main melodic version: nearly $80 \%$ of the chants studied in Lansdowne 461 follow the main melodic version, compared with only $15 \%$ of those in Cambridge Additional 2602;

- Individual witnesses may show very different influences on their contents: one manuscript is pitch-for-pitch identical with another in about $50 \%$ of the chants studied, 
but identical to only $7 \%$ of the chants in a third; in the case of a single manuscript, Bodl. Laud misc. 299 has nearly $80 \%$ of the office for Nicholas, but only $4 \%$ of that for Cecilia;

- A popular source of Sarum chants for modern editors, Cambridge Mm.II.9, is melodically close to an important manuscript (Lansdowne 461) and to the printed Antiphonal of 1519, suggesting it is in the central cluster of the manuscript tradition;

- A very early witness (the Seymour fragments) also shares close affinities with key later manuscripts at the centre of the tradition. Bodley 948 is almost as similar to the Seymour fragments as it is to its closest partner, Lansdowne 461;

- The two manuscripts (Bodley 948 and Lansdowne 461) which are most closely aligned are identical in only $48 \%$ of the chants studied. This is a significant proportion, but not an overwhelming one;

- Variants from the main melodic version are often shared between witnesses, usually affecting only a few pitches at a time; most variant readings are a result of more or fewer pitches than the main version.

Although further work with the chants of the Sanctorale will be necessary to establish whether these results are normative, the current picture is this: Sarum melodies for these four offices are undoubtedly stable, but individual witnesses of the melodies contain differences which are themselves the useful data that we have been able to consider. Some manuscripts are closely allied to others because they share a particular version of a melody; in these four offices, Camb. Mm.II.9 and the printed 1519-20 Antiphonal are about 30\% identical, pitch-for-pitch. The pair most closely related, Lansdowne 461 and Bodley 948, share $48 \%$ of their pitches. The Seymour 
fragments, too, are $46 \%$ identical to Lansdowne. It seems likely that these manuscripts represent the centre of the tradition along with Bodley 948, the Wollaton Antiphonal, and others.

Musico-liturgical research has moved away from a preoccupation with establishing the earliest and most authentic version of a rite or a chant. Single copies, or unrepresentative editions, have too long masked the diversity which lies between (and sometimes within) the bindings of late medieval liturgical manuscripts. This diversity, quantified for four Sarum offices in the points noted above, provides the student of medieval music or liturgy with challenging but rewarding opportunities to consider wider questions of transmission, memory, and textual stability. This study raises grave questions about choosing a convenient melodic source to stand in for others -and may force the question whether this practice is suitable in particular contexts. This of course assumes that precise melodic fidelity is something that we feel should exist and be valued, but perhaps this assumption too requires re-evaluation. Each of the manuscripts used in this study is identified as a 'Sarum' book: it is entirely possible, though, that they were used in contexts where comparable books might have been melodically different. If this is even possibly so, further consideration should be given to the ways that we study, and compare, written witnesses of melody from the Middle Ages. 
Table 1. Average numbers of witnesses sharing main melodic version by office and by service. The total number of witnesses is 13 .

\begin{tabular}{|l|l|l|l|l|}
\hline Office & Vespers & Matins & Lauds & Avg (all items) \\
\hline Assumption & 3.0 & 4.9 & 7.6 & 5.1 \\
\hline Cecilia & 4.5 & 3.4 & 4.7 & 3.7 \\
\hline Nicholas & 2.3 & 4.0 & 6.2 & 4.0 \\
\hline Peter and Paul & 4.0 & 5.4 & 6.0 & 5.3 \\
\hline All Offices & 3.5 & 4.4 & 6.1 & $\sim 4.5$ \\
\hline
\end{tabular}


Table 2. Appearance of main melodic version by feast in each witness. Percentages calculated by dividing the number of items containing the main melodic version by the number of items in which such a version exists. The office for Cecilia is not present where marked with -. The Seymour fragments are not included here as each office is fragmentary and unrepresentative figures would result.

\section{Assumption Cecilia Nicholas Peter and Paul}

\begin{tabular}{lcrcc} 
1519-20 Antiphonal & $66 \%$ & $74 \%$ & $58 \%$ & $68 \%$ \\
BL Additional 28598 & $40 \%$ & - & $21 \%$ & $15 \%$ \\
BL Lansdowne 461 & $77 \%$ & $93 \%$ & $63 \%$ & $79 \%$ \\
BL Lansdowne 463 & $74 \%$ & - & $38 \%$ & $65 \%$ \\
Bodl. Bodley 948 & $69 \%$ & $81 \%$ & $67 \%$ & $74 \%$ \\
Camb. Mm.II.9 & $69 \%$ & - & $67 \%$ & $62 \%$ \\
Camb. Additional 2602 & $20 \%$ & $4 \%$ & $25 \%$ & $18 \%$ \\
Bodl Lat.liturg.b.14 & $54 \%$ & $30 \%$ & $46 \%$ & $44 \%$ \\
Bodl Laud misc. 299 & $54 \%$ & $7 \%$ & $79 \%$ & $44 \%$ \\
NLW 20541.E & $34 \%$ & $7 \%$ & $33 \%$ & $24 \%$ \\
Ranworth & $57 \%$ & $52 \%$ & $63 \%$ & $71 \%$ \\
Wollaton & $54 \%$ & $78 \%$ & $75 \%$ & $65 \%$ \\
\hline Average for office & & & & $52 \%$ \\
\hline Standard deviation & $56 \%$ & $47 \%$ & $53 \%$ & \\
\hline & & $34 \%$ & $19 \%$ & \\
\hline
\end{tabular}


Table 3. Results by manuscript: numbers of items shared with at least one other witness, and number of items identical to the main melodic reading. Percentages given are out of a total of 164 items (for the former) and out of 123 items with a main melodic version.

\begin{tabular}{|l|l|l|}
\hline Witness & $\begin{array}{l}\text { No. of items in witness sharing a } \\
\text { melodic reading with at least 1 other } \\
\text { witness }\end{array}$ & $\begin{array}{l}\text { No of items sharing the main melodic } \\
\text { reading }\end{array}$ \\
\hline BL Lansdowne 461 & $99(60 \%)$ & $97(79 \%)$ \\
\hline Bodl. Bodley 948 & $97(59 \%)$ & $94(76 \%)$ \\
\hline Wollaton & $91(55 \%)$ & $86(70 \%)$ \\
\hline 1519/20 printed Antiphonal & $88(54 \%)$ & $82(67 \%)$ \\
\hline Ranworth & $84(51 \%)$ & $79(64 \%)$ \\
\hline Cambridge Mm.II.9 & 71 & $66 / 98(67 \%)^{*}$ \\
\hline BL Lansdowne 463 & $63(38 \%)$ & $59(48 \%)$ \\
\hline Bodl. Laud misc. 299 & $60(37 \%)$ & $54(44 \%)$ \\
\hline Bodl. Lat. liturg. b. 14 & $55(34 \%)$ & $53(43 \%)$ \\
\hline Seymour Fragments & 33 & $18(15 \%)$ \\
\hline NLW 20541.E & $33(20 \%)$ & $30(24 \%)$ \\
\hline Cambridge Additional 2602 & $21(13 \%)$ & \\
\hline & & \\
\hline & & $55 \%)^{*}$ \\
\hline
\end{tabular}

* Percentages out of the total are not given for two manuscripts which do not have transcriptions for every item. In Camb. Mm.II.9 the figures exclude the office for Cecilia which is incomplete at the end of the third Matins responsory. Only forty-eight items are present in the Seymour fragments. 
Table 4. Tables of affinity for each witness, compared with every other witness, giving the number of chants which are identical in each member of a pair, and the number of variants from the main melodic version shared by each pair.

\begin{tabular}{|l|l|r|r|c|}
\hline & & \multicolumn{1}{|c|}{$\begin{array}{c}\text { Identical } \\
\text { items }\end{array}$} & \multicolumn{1}{c|}{ identical } & variants \\
\hline 1519/20 Antiphonal & Bodley 948 & 65 & $39.63 \%$ & 5 \\
\hline & Lansdowne 461 & 65 & $39.63 \%$ & 4 \\
\hline & Ranworth & 58 & $35.37 \%$ & 5 \\
\hline & Wollaton & 54 & $32.93 \%$ & 6 \\
\hline & Mm.II.9 & 50 & $30.49 \%$ & 6 \\
\hline & Bodl Lat.liturg.b.14 & 46 & $28.05 \%$ & 4 \\
\hline & Bodl Laud misc.299 & 41 & $25.00 \%$ & 4 \\
\hline & Lansdowne 463 & 38 & $23.17 \%$ & 3 \\
\hline & NLW 20541.E & 23 & $14.02 \%$ & 8 \\
\hline & Seymour & 21 & $12.80 \%$ & 1 \\
\hline & BL Additional 28598 & 16 & $9.76 \%$ & 2 \\
\hline & Camb Additional & & & \\
\hline & 2602 & 9 & $5.49 \%$ & 0 \\
\hline
\end{tabular}

\begin{tabular}{|l|l|r|r|c|}
\hline & & $\begin{array}{r}\text { Identical } \\
\text { items }\end{array}$ & \multicolumn{1}{c|}{$\begin{array}{c}\text { Shared } \\
\text { identical }\end{array}$} & variants \\
\hline BL Additional 28598 & Mm.II.9 & 23 & $14.02 \%$ & 11 \\
\hline & Lansdowne 461 & 22 & $13.41 \%$ & 3 \\
\hline & Bodley 948 & 20 & $12.20 \%$ & 5 \\
\hline & Wollaton & 20 & $12.20 \%$ & 5 \\
\hline & Lansdowne 463 & 19 & $11.59 \%$ & 8 \\
\hline
\end{tabular}




\begin{tabular}{|l|l|r|r|c|}
\hline & Bodl Laud misc.299 & 18 & $10.98 \%$ & 4 \\
\hline & Ranworth & 16 & $9.76 \%$ & 3 \\
\hline & $1519 / 20$ Antiphonal & 16 & $9.76 \%$ & 2 \\
\hline & Bodl Lat.liturg.b.14 & 12 & $7.32 \%$ & 13 \\
\hline & NLW 20541.E & 11 & $6.71 \%$ & 9 \\
\hline & Camb Additional & & & \\
& 2602 & 9 & $5.49 \%$ & 23 \\
\hline & Seymour & 6 & $3.66 \%$ & 1 \\
\hline
\end{tabular}

\begin{tabular}{|l|l|r|r|c|}
\hline & & \multicolumn{1}{|c|}{$\begin{array}{c}\text { Identical } \\
\text { items }\end{array}$} & \multicolumn{1}{c|}{ identical } & variants \\
\hline Lansdowne 461 & Bodley 948 & 80 & $48.78 \%$ & 6 \\
\hline & Wollaton & 68 & $41.46 \%$ & 6 \\
\hline & $1519 / 20$ Antiphonal & 65 & $39.63 \%$ & 4 \\
\hline & Ranworth & 58 & $35.37 \%$ & 4 \\
\hline & Mm.II.9 & 51 & $31.10 \%$ & 5 \\
\hline & Bodl Laud misc.299 & 44 & $26.83 \%$ & 6 \\
\hline & Bodl Lat.liturg.b.14 & 43 & $26.22 \%$ & 7 \\
\hline & Lansdowne 463 & 43 & $26.22 \%$ & 2 \\
\hline & BL Additional 28598 & 22 & $13.41 \%$ & 3 \\
\hline & Seymour & 22 & $13.41 \%$ & 1 \\
\hline & Camb Additional & & & \\
\hline & 2602 & 12 & $7.32 \%$ & 4 \\
\hline & & & & \\
\hline
\end{tabular}

\begin{tabular}{|l|l|r|r|c|}
\hline & & $\begin{array}{c}\text { Identical } \\
\text { items }\end{array}$ & $\begin{array}{c}\% \\
\text { identical }\end{array}$ & $\begin{array}{c}\text { Shared } \\
\text { variants }\end{array}$ \\
\hline Lansdowne 463 & Wollaton & 47 & $28.66 \%$ & 9 \\
\hline
\end{tabular}




\begin{tabular}{|l|l|r|r|c|}
\hline & Ranworth & 44 & $26.83 \%$ & 4 \\
\hline & Lansdowne 461 & 43 & $26.22 \%$ & 2 \\
\hline & Bodley 948 & 42 & $25.61 \%$ & 4 \\
\hline & $1519 / 20$ Antiphonal & 38 & $23.17 \%$ & 3 \\
\hline & Mm.II.9 & 36 & $21.95 \%$ & 2 \\
\hline & Bodl Lat.liturg.b.14 & 29 & $17.68 \%$ & 4 \\
\hline & Bodl Laud misc.299 & 28 & $17.07 \%$ & 2 \\
\hline & BL Additional 28598 & 19 & $11.59 \%$ & 8 \\
\hline & NLW 20541.E & 17 & $10.37 \%$ & 2 \\
\hline & Camb Additional & & & 7 \\
\hline & 2602 & 13 & $7.93 \%$ & 7 \\
\hline & Seymour & 9 & $5.49 \%$ & 0 \\
\hline
\end{tabular}

\begin{tabular}{|l|l|r|r|c|}
\hline & & \multicolumn{1}{|c|}{$\begin{array}{c}\text { Identical } \\
\text { items }\end{array}$} & \multicolumn{1}{c|}{ identical } & variants \\
\hline Bodley 948 & Lansdowne 461 & 80 & $48.78 \%$ & 6 \\
\hline & Wollaton & 66 & $40.24 \%$ & 6 \\
\hline & $1519 / 20$ Antiphonal & 65 & $39.63 \%$ & 5 \\
\hline & Ranworth & 63 & $38.41 \%$ & 4 \\
\hline & Mm.II.9 & 47 & $28.66 \%$ & 2 \\
\hline & Bodl Lat.liturg.b.14 & 42 & $25.61 \%$ & 6 \\
\hline & Lansdowne 463 & 42 & $25.61 \%$ & 5 \\
\hline & Bodl Laud misc.299 & 39 & $23.78 \%$ & 5 \\
\hline & NLW 20541.E & 28 & $17.07 \%$ & 5 \\
\hline & Seymour & 22 & $13.41 \%$ & 2 \\
\hline & BL Additional 28598 & 20 & $12.20 \%$ & 6 \\
\hline & Camb Additional & 16 & $9.76 \%$ & 16 \\
\hline & & & & 5 \\
\hline
\end{tabular}




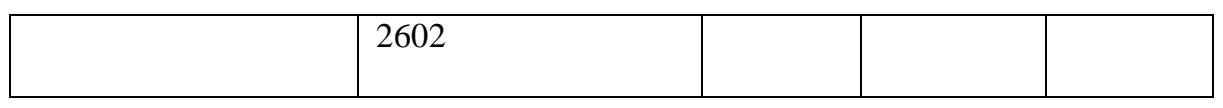

\begin{tabular}{|l|l|r|r|c|}
\hline & & \multicolumn{1}{|c|}{$\begin{array}{c}\text { Identical } \\
\text { items }\end{array}$} & \multicolumn{1}{c|}{$\begin{array}{c}\text { Shared } \\
\text { identical }\end{array}$} & variants \\
\hline Mm.II.9 & Lansdowne 461 & 51 & $31.10 \%$ & 5 \\
\hline & $1519 / 20$ Antiphonal & 50 & $30.49 \%$ & 6 \\
\hline & Bodley 948 & 47 & $28.66 \%$ & 2 \\
\hline & Ranworth & 45 & $27.44 \%$ & 4 \\
\hline & Bodl Laud misc.299 & 44 & $26.83 \%$ & 6 \\
\hline & Wollaton & 44 & $26.83 \%$ & 4 \\
\hline & Lansdowne 463 & 36 & $21.95 \%$ & 2 \\
\hline & Bodl Lat.liturg.b.14 & 35 & $21.34 \%$ & 6 \\
\hline & NLW 20541.E & 24 & $14.63 \%$ & 11 \\
\hline & BL Additional 28598 & 23 & $14.02 \%$ & 11 \\
\hline & Seymour & 15 & $9.15 \%$ & 1 \\
\hline & Camb Additional & & & 8 \\
\hline & 2602 & 10 & $6.10 \%$ & 8 \\
\hline
\end{tabular}

\begin{tabular}{|l|l|r|r|c|}
\hline & & $\begin{array}{r}\text { Identical } \\
\text { items }\end{array}$ & \multicolumn{1}{c|}{$\begin{array}{c}\text { Shared } \\
\text { identical }\end{array}$} & variants \\
\hline Camb Additional & & & & \\
& Ranworth & 17 & $10.37 \%$ & 5 \\
\hline & Bodley 948 & 16 & $9.76 \%$ & 15 \\
\hline & Wollaton & 14 & $8.54 \%$ & 10 \\
\hline & Lansdowne 463 & 13 & $7.93 \%$ & 7 \\
\hline & Lansdowne 461 & 12 & $7.32 \%$ & 4 \\
\hline & Mm.II.9 & 10 & $6.10 \%$ & 8 \\
\hline
\end{tabular}




\begin{tabular}{|l|l|r|r|r|}
\hline & BL Additional 28598 & 9 & $5.49 \%$ & 23 \\
\hline & $1519 / 20$ Antiphonal & 9 & $5.49 \%$ & 0 \\
\hline & Bodl Lat.liturg.b.14 & 8 & $4.88 \%$ & 17 \\
\hline & Bodl Laud misc.299 & 7 & $4.27 \%$ & 13 \\
\hline & NLW 20541.E & 6 & $3.66 \%$ & 32 \\
\hline & Seymour & 5 & $3.05 \%$ & 4 \\
\hline
\end{tabular}

\begin{tabular}{|c|c|c|c|c|}
\hline & & $\begin{array}{l}\text { Identical } \\
\text { items }\end{array}$ & $\begin{array}{c}\% \\
\text { identical }\end{array}$ & $\begin{array}{l}\text { Shared } \\
\text { variants }\end{array}$ \\
\hline \multirow[t]{12}{*}{ Bodl Lat.liturg.b.14 } & 1519/20 Antiphonal & 46 & $28.05 \%$ & 4 \\
\hline & Lansdowne 461 & 43 & $26.22 \%$ & 7 \\
\hline & Bodley 948 & 42 & $25.61 \%$ & 6 \\
\hline & Ranworth & 40 & $24.39 \%$ & 8 \\
\hline & Wollaton & 36 & $21.95 \%$ & 7 \\
\hline & Mm.II.9 & 35 & $21.34 \%$ & 6 \\
\hline & Lansdowne 463 & 29 & $17.68 \%$ & 4 \\
\hline & Bodl Laud misc. 299 & 28 & $17.07 \%$ & 15 \\
\hline & NLW 20541.E & 21 & $12.80 \%$ & 17 \\
\hline & BL Additional 28598 & 12 & $7.32 \%$ & 13 \\
\hline & Seymour & 10 & $6.10 \%$ & 5 \\
\hline & $\begin{array}{l}\text { Camb Additional } \\
2602\end{array}$ & 8 & $4.88 \%$ & 17 \\
\hline
\end{tabular}

\begin{tabular}{|l|l|r|r|c|}
\hline & & \multicolumn{1}{|c|}{$\begin{array}{c}\text { Identical } \\
\text { items }\end{array}$} & identical & variants \\
\hline Bodl Laud misc.299 & Lansdowne 461 & 44 & $27.83 \%$ & 6 \\
\hline & Mm.II.9 & 44 & $26.83 \%$ & 6 \\
\hline
\end{tabular}




\begin{tabular}{|l|l|r|r|c|}
\hline & $1519 / 20$ Antiphonal & 41 & $25.00 \%$ & 4 \\
\hline & Bodley 948 & 39 & $23.78 \%$ & 5 \\
\hline & Wollaton & 38 & $23.17 \%$ & 5 \\
\hline & Ranworth & 36 & $21.95 \%$ & 8 \\
\hline & Bodl Lat.liturg.b.14 & 28 & $17.07 \%$ & 15 \\
\hline & Lansdowne 463 & 28 & $17.07 \%$ & 2 \\
\hline & BL Additional 28598 & 18 & $10.98 \%$ & 4 \\
\hline & NLW 20541.E & 16 & $9.76 \%$ & 12 \\
\hline & Seymour & 15 & $9.15 \%$ & 3 \\
\hline & Camb Additional & & & \\
\hline & 2602 & 7 & $4.27 \%$ & 13 \\
\hline
\end{tabular}

\begin{tabular}{|l|l|r|r|c|}
\hline & & \multicolumn{1}{|c|}{$\begin{array}{c}\text { Identical } \\
\text { items }\end{array}$} & \multicolumn{1}{c|}{ Shared } \\
& & 28 & $17.07 \%$ & 11 \\
\hline NLW 20541.E & Lansdowne 461 & 28 & $17.07 \%$ & 5 \\
\hline & Bodley 948 & 24 & $14.63 \%$ & 11 \\
\hline & Mm.II.9 & 23 & $14.02 \%$ & 8 \\
\hline & 1519/20 Antiphonal & 22 & $13.41 \%$ & 3 \\
\hline & Wollaton & 21 & $12.80 \%$ & 17 \\
\hline & Bodl Lat.liturg.b.14 & 21 & $12.80 \%$ & 10 \\
\hline & Ranworth & 17 & $10.37 \%$ & 2 \\
\hline & Lansdowne 463 & 16 & $9.76 \%$ & 12 \\
\hline & Bodl Laud misc.299 & 11 & $6.71 \%$ & 9 \\
\hline & BL Additional 28598 & & $4.27 \%$ & 3 \\
\hline & Seymour & & $3.66 \%$ & 32 \\
\hline & Camb Additional & & & \\
\hline & 2602 & & & \\
\hline
\end{tabular}




\begin{tabular}{|l|l|r|r|c|}
\hline & & \multicolumn{1}{|c|}{$\begin{array}{c}\text { Identical } \\
\text { items }\end{array}$} & \multicolumn{1}{c|}{ identical } & variants \\
\hline Ranworth & Bodley 948 & 63 & $38.41 \%$ & 4 \\
\hline & Wollaton & 62 & $37.80 \%$ & 12 \\
\hline & $1519 / 20$ Antiphonal & 58 & $35.37 \%$ & 5 \\
\hline & Lansdowne 461 & 58 & $35.37 \%$ & 4 \\
\hline & Mm.II.9 & 45 & $27.44 \%$ & 4 \\
\hline & Lansdowne 463 & 44 & $26.83 \%$ & 4 \\
\hline & Bodl Lat.liturg.b.14 & 40 & $24.39 \%$ & 8 \\
\hline & Bodl Laud misc.299 & 36 & $21.95 \%$ & 8 \\
\hline & NLW 20541.E & 21 & $12.80 \%$ & 10 \\
\hline & Seymour & 18 & $10.98 \%$ & 0 \\
\hline & Camb Additional & & & \\
\hline & BL02 & 17 & $10.37 \%$ & 5 \\
\hline & BL Additional 28598 & 16 & $9.76 \%$ & 3 \\
\hline
\end{tabular}

\begin{tabular}{|c|c|c|c|c|}
\hline & & $\begin{array}{l}\text { Identical } \\
\text { items }\end{array}$ & $\begin{array}{c}\% \\
\text { identical } \\
\text { (out of } \\
48 \text { ) }\end{array}$ & $\begin{array}{l}\text { Shared } \\
\text { variants }\end{array}$ \\
\hline \multirow[t]{6}{*}{ Seymour } & Bodley 948 & 22 & $45.83 \%$ & 2 \\
\hline & Lansdowne 461 & 22 & $45.83 \%$ & 1 \\
\hline & 1519/20 Antiphonal & 21 & $43.75 \%$ & 1 \\
\hline & Wollaton & 19 & $39.58 \%$ & 4 \\
\hline & Ranworth & 18 & $37.50 \%$ & 0 \\
\hline & Bodl Laud misc.299 & 15 & $31.25 \%$ & 3 \\
\hline
\end{tabular}




\begin{tabular}{|l|l|r|r|r|}
\hline & Mm.II.9 & 15 & $31.25 \%$ & 1 \\
\hline & Bodl Lat.liturg.b.14 & 10 & $20.83 \%$ & 5 \\
\hline & Lansdowne 463 & 9 & $18.75 \%$ & 0 \\
\hline & NLW 20541.E & 7 & $14.58 \%$ & 3 \\
\hline & BL Additional 28598 & 6 & $12.50 \%$ & 1 \\
\hline & Camb Additional & & & $10.42 \%$ \\
& 2602 & 5 & & 4 \\
\hline
\end{tabular}

\begin{tabular}{|c|c|c|c|c|}
\hline & & $\begin{array}{c}\text { Identical } \\
\text { items }\end{array}$ & $\begin{array}{c}\% \\
\text { identical }\end{array}$ & $\begin{array}{l}\text { Shared } \\
\text { variants }\end{array}$ \\
\hline \multirow[t]{12}{*}{ Wollaton } & Lansdowne 461 & 68 & $41.46 \%$ & 6 \\
\hline & Bodley 948 & 66 & $40.24 \%$ & 6 \\
\hline & Ranworth & 62 & $37.80 \%$ & 12 \\
\hline & 1519/20 Antiphonal & 54 & $32.93 \%$ & 6 \\
\hline & Lansdowne 463 & 47 & $28.66 \%$ & 9 \\
\hline & Mm.II.9 & 44 & $26.83 \%$ & 4 \\
\hline & Bodl Laud misc.299 & 38 & $23.17 \%$ & 5 \\
\hline & Bodl Lat.liturg.b.14 & 36 & $21.95 \%$ & 7 \\
\hline & NLW 20541.E & 22 & $13.41 \%$ & 3 \\
\hline & BL Additional 28598 & 20 & $12.20 \%$ & 5 \\
\hline & Seymour & 19 & $11.59 \%$ & 4 \\
\hline & $\begin{array}{l}\text { Camb Additional } \\
2602\end{array}$ & 14 & $8.54 \%$ & 10 \\
\hline
\end{tabular}

${ }^{1}$ Richard W. Pfaff, The Liturgy in Medieval England: a history (Cambridge: Cambridge University Press, 2009) (henceforth $L M E$ ), 350. Indeed, even in 1780 the antiquarian Richard Gough remarked that he would 'leave it to the connoisseurs in music to determine whether the Sarum chant differed from that of York, Bangor or Hereford'. 
Richard Gough, British Topography, new ed. (London, 1780), vol. 2, 321 (emphasis original). Roger Bowers and others favour 'the Use of Salisbury' as preferable to the peculiar expansion of a contraction, noting that liturgiologists 'have - inconsistently but very properly - refrained from referring to any such monsters as the "Herf Use", or the "Use of Eborum"'. 'Sarum', for Bowers is 'unhistorical, inconsistent and unscholarly' See Roger Bowers, 'Choral Institutions within the English Church: Their Constitution and Development 1340-1500' (unpublished doctoral thesis, University of East Anglia, 1975), 2014 (note that four-digit numbers here do refer to pagination). The present author uses 'Sarum', partly for the sake of consistency with previous scholarship, to refer to the transregional liturgical pattern of the later Middle Ages and 'Salisbury' to refer only to the cathedral and its liturgy.

${ }^{2}$ A historiographical survey of scholarship in this area may be found in Matthew Cheung Salisbury, 'Rethinking the Uses of Sarum and York: a historiographical essay', in Understanding Medieval Liturgy: essays in interpretation, edited by Sarah Hamilton and Helen Gittos (Farnham: Ashgate, 2015), 103-122. For printed liturgical books, see Andrew Hughes et al, Cataloguing Discrepancies: the printed York Breviary of 1493 (Toronto: University of Toronto Press, 2011) and Matthew Cheung Salisbury, 'Early printed books and the modern resources that describe them: the case of the Hereford Breviary of 1505', in The Perils of Print Culture, edited by Jason McElligott and Eve Patten (Basingstoke: Palgrave Macmillan, 2014), 51-63. Barbara Haggh and Sarah Ann Long have considered the editorial process incumbent in producing liturgical books for other regions: see Barbara Haggh, 'The First Printed Antiphoner of Cambrai Cathedral', in Gestalt und Enstehung musikalischer Quellen im 15. und 16. Jahrhundert, ed. by Martin Staehelin (Wiesbaden: Harrassowitz, 1998), pp.75-103; and Sarah Ann Long, 'The Chanted Mass in Parisian Ecclesiastical and Civic Communities, 1480-1540: Local Liturgical Practices in Manuscripts and Early Printed Service Books' (unpublished PhD thesis, University of Illinois at Urbana-Champaign, 2008). Both identify the influence of various factors on the production of service books. Cambrai is an example of another diocese where only one printed Antiphonal was produced in the Middle Ages, also in Paris (by Simon Vostre).

${ }^{3}$ Frere's Antiphonale is, as advertised in the subtitle, 'a reproduction in facsimile of a Manuscript of the thirteenth century, with a dissertation and analytical index by W.H. Frere.' The manuscript in question is Cambridge, University Library Mm.II.9, which Frere attributes to Barnwell, Cambridgeshire on the basis of local observance of saints. Both the beginning and the end of Mm.II.9 are imperfect, so Frere supplemented it where lacking with 
facsimiles of Salisbury Cathedral MS 152, Oxford, Bodleian Library, Bodley 948, and a few images of the printed Sarum Antiphonal of 1519/1520.

${ }^{4}$ Richard Pfaff identifies this heterogeneity throughout $L M E$. Barbara Haggh suggests that the illusion of uniformity amongst liturgical sources 'reflect[s] post-Tridentine and post-Vatican II thinking' (p.372); in the case of Cambrai, 'the first sources to refer to a diocesan Use of Cambrai are printed ones.' (p.387). Sherry Reames has identified families of variants in Sarum Office lessons in five separate publications, most recently 'Unexpected Texts for Saints in Some Sarum Breviary Manuscripts', in The Study of Medieval Manuscripts of England: Festschrift in Honor of Richard W. Pfaff, ed. by George Hardin Brown and Linda Ehrsam Voigts (Turnhout: Brepols, 2010), 16384. A comprehensive study of Office books from England may be found in Salisbury, The Secular Liturgical Office in Late Medieval England (Turnhout: Brepols, 2015), which uses evidence from nearly 200 liturgical books to show the types of textual variants they contain. For a discussion of the variation in chants for the votive Lady Mass in Sarum manuscripts and printed books, see the apparatus to John Harper, Sally Harper, and Matthew Salisbury, Lady Mass according to the Use of Salisbury, Early English Church Music 58 (Stainer and Bell for the British Academy, forthcoming 2017).

${ }^{5}$ The best study of the printed Sarum Antiphonal is Magnus Williamson, 'Affordable splendour: editing, printing, and marketing the Sarum Antiphoner (1519-20) Renaissance Studies 26.1 (2012), 60-87.

${ }^{6}$ See Anselm Hughes, Septuagesima: Reminiscences of the Plainsong and Mediaeval Music Society, and of Other Things Personal and Musical (London: Plainsong and Mediaeval Music Society, 1959), 21, 34.

${ }^{7}$ The other principal editorial projects to which one may have recourse are The Use of Salisbury, ed. by Nicholas Sandon, in 6 vols (Moretonhampstead, Newton Abbot: Antico, 1990-1999), editions of the Ordinary and the Proper of the Mass; and The Sarum Rite, ed. by William Renwick (published online at http://hmcwordpress.mcmaster.ca/renwick/), 'a multi-volume performing and scholarly edition of all the surviving liturgy and music of the Sarum Rite'. Renwick's resource, which is an excellent pragmatic resource for performance, takes as its principal sources the modern reprint of the 1531 printed Breviary (for whose deficiencies see Salisbury, SLO, chapter 1) and the manuscripts of Frere's Antiphonale Sarisburiense, supplementing absent contents from several printed editions including the 1519-20 Antiphonal.

${ }^{8}$ René-Jean. Hesbert, Corpus Antiphonalium Officii, Rerum Ecclesiasticarum Documenta Series Maior 7-12, 6 vols (Rome: Herder, 1963-79). 
${ }^{9}$ Pfaff $L M E, 429$.

${ }^{10}$ For a summary see Salisbury, The Secular Liturgical Office.

${ }^{11}$ Pfaff correctly contradicts this assessment: there was a 'self-conscious' and detailed Sarum tradition which dated from before 1220 and Bishop Poore. LME, 364.

${ }^{12}$ The Experience of Worship in late medieval Cathedral and Parish Church, led by John Harper and Sally Harper at Bangor University, is introduced in an Arts and Humanities Research Council case-study here:

http://www.ahrc.ac.uk/research/casestudies/experience-of-worship/

${ }^{13}$ Salisbury, The Secular Liturgical Office

${ }^{14}$ Useful studies which exemplify the trans-regional approach include Peter Underwood, 'Melodic traditions in medieval English antiphoners' Journal of the Plainsong and Mediaeval Music Society 5 (1982), 1-12, and David Hiley, 'Thurstan of Caen and Plainchant at Glastonbury: musicological reflections on the Norman conquest' Proceedings of the British Academy 72 (1986), 57-90.

${ }^{15}$ Among many others, references to Frere's Antiphonale as a representative witness of Sarum chant may be found in such studies as John D. Bergsagel, 'An Introduction to Ludford (c.1485-c.1557)’ Musica Disciplina 14 (1960), 105-130; Hans-Jorgen Holman, 'Melismatic Tropes in the Responsories for Matins' Journal of the American Musicological Society 16.1 (1963), 36-46; Shai Burstyn, 'Power's “Anima mea” and Binchois' "De plus en plus”: A Study in Musical Relationships', Musica Disciplina 30 (1976), 55-72; Magnus Williamson, 'Royal Image-Making and Textual Interplay in Gilbert Banaster's 'O Maria et Elizabeth', Early Music History 19 (2000), 237-278; Kate Helsen, 'Evidence for the Oral Transmission of the Great Responsories’, Acta musicologica 83.2 (2011), 181-204.

${ }^{16}$ Suppose, for instance, the material being edited was a work by a canonical author.

${ }^{17}$ It also seems likely that the large noted breviary Salisbury Cathedral Library MS 224 (formerly Bodleian e Mus 2) was at Bedwyn from the late fourteenth century until the late fifteenth century.

${ }^{18}$ Graham Bathe and John Harper, 'Fragments of Sarum Liturgy in the Seymour Family Archives', Wiltshire Archaelogical and Natural History Magazine 108 (2015), 159-184 (165).

${ }^{19}$ Bathe and Harper, 167. The Temporale supplies contents from Advent until Christmas Day, and then Trinity Sunday and the days following. The Common of Saints part of Matins, Lauds, and Terce for Apostles, part of Matins for One Martyr; None to Second Vespers on feasts of a Confessor also Abbot, First Vespers and most of Matins for Several Confessors. 
${ }^{20}$ Bathe and Harper, 165, 168.

${ }^{21}$ The addition of the feast of St Edmund of Abingdon suggests it may have been made prior to 1246, and it is noted that the manuscript was still in use beyond the suppression of the feast of St Thomas Becket in 1536. Bathe and Harper, 168.

${ }^{22}$ Bathe and Harper, 166.

${ }^{23}$ Williamson, 'Affordable splendour', 60, 85.

${ }^{24}$ Ibid., 71.

${ }^{25}$ Ibid., 73.

${ }^{26}$ Ibid., 77. See also Haggh, 'First Printed Antiphoner' and Long’s thesis, supra.

${ }^{27}$ The texts and (one reading of) the chants for these four offices may readily be consulted in Frere's Antiphonale or in the 1519/20 printed Antiphonal.

${ }^{28}$ The introductory dissertation of Frere's Antiphonale is the first significant study of responsory chants; others include Ruth Steiner, 'The Responsories and Prosa for St Stephen's Day at Salisbury' The Musical Quarterly 56.2 (1970), 162-182, and Kate Helsen, 'Evidence for the Oral Transmission of the Great Responsories'.

${ }^{29}$ A statistical calculation indicating the spread of a group of observed values: a high standard deviation indicates the spread is considerable; a low standard deviation indicates most values are close to the average. In this case, a high standard deviation indicates deviance from the main melodic version, and a low standard deviation closeness to it.

${ }^{30}$ It should also be noted that, probably as a result of its being near the end of the Sanctorale and therefore prone to manuscript damage or wear, the entirety of Cecilia's Office is absent from BL Additional 28598 and Lansdowne 463, and it is incomplete in Cambridge Mm.II.9 and the Seymour fragments (these zero results are not considered in the calculations)

${ }^{31}$ See Timothy Morris, 'The Augustinian Use of Oseney Abbey: A Study of the Oseney Ordinal, Processional, and Tonale (Bodleian Library MS Rawlinson c. 939)' (unpublished doctoral thesis, University of Oxford, 1999), and Anna Parsons [now Howard], 'The Use of Guisborough: The Liturgy and Chant of the Augustinian Canons of the York Province in the later Middle Ages' (unpublished doctoral thesis, University of Exeter, 2004).

32 
${ }^{33}$ Owain Tudor Edwards, 'How Many Sarum Antiphonals were there in England and Wales in the Middle of the Sixteenth Century?’ Revue Bénédictine 99 (1989), 155-180.

${ }^{34}$ Edwards, 176.

${ }^{35}$ Pfaff $L M E, 511$.

${ }^{36}$ Williamson, ‘Affordable splendour', 62.

${ }^{37}$ Frank Harrison, Music in Medieval Britain (New York: Frederick A. Praeger, 1959), 103.

${ }^{38}$ Maurice F. Bond, Inventories of St George's Chapel Windsor Castle 1384-1667 (Windsor: The Dean and Canons of St George's Chapel, 1947), 32-34.

${ }^{39}$ Harrison, 102.

${ }^{40}$ Bowers, 2006.

${ }^{41}$ Ibid., 2016-2017.

${ }^{42}$ Cited in Bowers, 2022.

${ }^{43}$ Ibid., 3021.

${ }^{44}$ Ibid., 3022.

${ }^{45}$ See Haggh, 'First Printed Antiphoner', 97. 